\title{
Environmental effects on picloram uptake and ethylene production by broom snakeweed
}

\author{
TRACY M. STERLING, NORMAN K. LOWNDS, AND LEIGH W. MURRAY
}

\begin{abstract}
Authors are associate professor, Entomology, Plant Pathology and Weed Science Department, New Mexico State University, Las Cruces, N.M. 88003-0003; associate professor, Agronomy and Horticulture Department, New Mexico State University, Las Cruces, N.M. 88003-0003; and associate professor, Department of Experimental Statistics, New Mexico State University, Las Cruces, N.M. 88003-0003, respectively.
\end{abstract}

\begin{abstract}
Broom snakeweed [Gutierrezia sarothrae (Pursh) Britt. \& Rusby] is a rangeland weed widely distributed in the western United States. Picloram (4-amino-3,5,6-trichloro-2-pyridinecarboxylic acid) uptake and picloram-induced ethylene production by broom snakeweed grown in the field were determined every 2 to 4 weeks over 36 months. For each collection date, picloram uptake and concentration in the tissue ranged from 1.5 to $46.2 \%$ of applied and 0.2 to $4.7 \mathrm{nmol} \mathrm{g}^{-1}$ fresh wt, respectively. Of the measured environmental variables, average precipitation and average minimum temperature 7 days prior to treatment best predicted picloram uptake and concentration in the tissue, suggesting that warmer temperatures and precipitation previous to application contribute to picloram uptake. Average minimum temperature alone also provided a good predictor for picloram concentration in the tissue. For each collection date, picloraminduced ethylene production by total tissue ranged from 50 to $791 \%$ of control. Picloram-induced ethylene production by total tissue was best predicted by the precipitation and minimum temperature 7 days prior to treatment and picloram concentration in the tissue. Therefore, the amount of picloram absorbed and the environment prior to application both contribute to the physiological sensitivity of broom snakeweed to picloram. Picloram uptake and picloram-induced ethylene production were greatest in July and August, when plants were in the phenological stages of shoot regreening or flower bud emergence and when temperatures and precipitation were high. Previous field studies have shown broom snakeweed is most responsive to field picloram application in the post-bloom stage from October to December or in April and May with high moisture and soil temperature conditions; therefore, it appears that changes in uptake and physiological sensitivity as measured by picloram-induced ethylene production are not the only factors controlling differential sensitivity to picloram.
\end{abstract}

Key Words: Gutierrezia sarothrae, herbicide absorption, picloram-induced ethylene, ethylene, temperature, precipitation.

Research supported by the New Mexico Agr. Exp. Sta. and a USDA-CSRS Special Grant 89-34196-4872.

Manuscript accepted 8 Jul. 1995.
Broom snakeweed [Gutierrezia sarothrae (Pursh) Britt. \& Rusby] is a suffrutescent shrub widely distributed in the western United States from Canada to northern Mexico (Lane 1985). This weed interferes with forage production (McDaniel et al. 1982) and is poisonous to livestock (McDaniel and Duncan 1987). Picloram (4-amino-3,5,6-trichloro-2-pyridinecarboxylic acid) is the primary herbicide used for control of broom snakeweed but control using herbicides varies (McDaniel and Duncan 1987). Differential herbicide uptake into the plant may explain some of this variability. Picloram uptake by broom snakeweed leaves has been characterized in laboratory studies; uptake was complete within $15 \mathrm{~min}$ of application and increased with temperature or relative humidity at and following application (Sterling and Lownds 1992).

Picloram is an auxin-like herbicide, inducing ethylene production (Fedtke 1982) followed by morphological changes such as epinasty (Hall et al. 1985). Induction of the plant hormone ethylene in plants is dependent on environmental conditions and stage of plant growth (Yang et al. 1990) and the role picloram-induced ethylene production plays in picloram action is unclear (Fedtke 1982, Hall et al. 1985). Auxin-induced ethylene production has been suggested as an index of auxin or auxin-like herbicide uptake (Lownds et al. 1987). Understanding the effects of environment prior to application on picloram uptake may enable ranchers to increase the efficacy of their herbicide applications. Therefore, the specific objectives of this study using field-grown broom snakeweed plants were to examine the relationship between picloram uptake by broom snakeweed leaf tissue and temperature and precipitation prior to herbicide application and the relationship between picloram-induced ethylene production by broom snakeweed and herbicide uptake, temperature and precipitation prior to herbicide application.

\section{Materials and Methods}

Time-course of Picloram-induced Ethylene Production

Broom snakeweed plants (ca. $20 \mathrm{~cm}$ tall) were collected in May 1990 from the USDA-ARS Jornada Experimental Range located ca. $30 \mathrm{~km}$ northeast of Las Cruces, N.M. Plants were transplanted by placing the root ball containing field soil into $15-\mathrm{cm}$ diameter pots containing potting soil (Terra-Lite Metro Mix 350, W. R. Grace \& Co., Memphis, Tenn. 38103). Plants were maintained in 
the greenhouse, fertilized weekly with 2.5 g liter $^{-1}$ 20:10:20 (N:P:K) and watered daily until herbicide application. This experiment was performed 8 months after transplanting in January 1990 and repeated in June 1990, 13 months after transplanting. Individual plants wcre sprayed with formulated picloram at 0 , $0.14,0.28$, and $0.56 \mathrm{~kg}$ ae ha ${ }^{-1}$ in a carrier volume of 187 liter ha-1 using a backpack sprayer. Soil was covered with vermiculite to prevent herbicide application to soil; vermiculite was removed immediately after herbicide application.

Ethylene production by excised shoot tips (ca. $10 \mathrm{~cm}$ long) was measured at $0,24,48,72,120$, and 168 hours after herbicide treatment. At each time point, tissues were weighed and placed in $10-\mathrm{ml}$ test tubes and capped. Tubes were incubated at $30^{\circ} \mathrm{C}$ for 2 hours after which ethylene production was determined by removing a 1-ml headspace sample and ethylene quantitated using gas chromatography as described by Morrison et al. (1995). Plant injury was visually rated weekly for 16 weeks after treatment.

The experiment was arranged as a randomized-complete-block design with 3 replications. Treatments were 4 rates of picloram and plants were blocked by size and location in the greenhouse. Data were subjected to analysis of variance. Because the treatment by date interaction was not significant, data from the 2 experiments were combined. Means and standard errors were calculated on the combined data.

\section{Herbicide Uptake and Induced Ethylene Production in the Field}

Twenty-four plants were permanently marked near the Coop Well (32 $\left.34^{\circ} 8^{\prime \prime} \mathrm{N}, 106^{\circ} 48^{\prime} 39^{\prime \prime} \mathrm{W}\right)$ on the USDA-ARS Jornada Experimental Range; 3 parallel transects running south to north within a 60 - by 20 -m area each contained 1 set of 8 individual plants chosen so the first plant of each transect was of uniform size and location (near south end of transect) and the second plant of each transect was of uniform size and location (north of first plant from each respective transect), repeating through the eighth plant of each transect of uniform size and location, near the north end of each respective transect. Every 2 to 4 weeks from April 1990 through April 1993 between 0800 and 1000 hours MST for a total of 66 dates, 2 stems (ca. $10 \mathrm{~cm}$ long and ca. $0.2 \mathrm{~g}$ fresh weight) were excised from each of 8 plants from 1 set. Green stems were excised from a similar position on each of 8 plants within 1 plant set for each specific harvest date with sampling from the entire plant across the course of the experiment. Two additional sets of 8 plants were used when the plants of the first set no longer possessed enough stems due to sampling or herbivory. Cut stem ends were submerged in $15-\mathrm{ml}$ vials containing 2-ml distilled water and all samples were brought to the lab and treated within 2 hours of excision. Phenological stage (Depuit and Caldwell 1975) was estimated from photographs of plants taken on treatment dates.

Picloram was applied using methods modified from Sterling and Lownds (1992). Picloram was applied as its potassium salt in five $0.25 \mu \mathrm{l}$ droplets $(770 \mu \mathrm{m}$ diam) per leaf to the adaxial surface of 2 leaves located 2 to $3 \mathrm{~cm}$ from the shoot apex of each of the 8 stems within a plant set. An additional 8 stems from respective plants within the same plant set served as untreated controls for baseline ethylene determination. Treatment solutions contained $266 \mathrm{MBq} \mathrm{m}{ }^{-1}$ of picloram-2,6- ${ }^{14} \mathrm{C}$ and unlabelled-picloram ( $>99 \%$ purity) to reach a final concentration of $6.2 \mathrm{mM}$ (equivalent to $0.25 \mathrm{~kg}$ ae ha-1 at 187 liters ha-1) with equimolar $\mathrm{KOH}$ to solubilize picloram acid, obtaining a final $\mathrm{pH}$ of 9.5. Immediately following droplet application, stems were placed in a growth chamber at $28 / 20^{\circ} \mathrm{C}$ day/night temperatures and $50 \pm 5 \%$ relative humidity; photoperiod was 16 hours with a light intensity of 150 $\mu \mathrm{E} \mathrm{m} \mathrm{m}^{-2} \mathrm{~s}^{-1}$ photosynthetic photon flux. Twenty-four hours after treatment, treated leaves were removed from the stems and surface picloram residue was removed with two $1-\mathrm{ml}$ rinses of $50 \%$ aqueous methanol. Stems were separated into treated leaves and untreated (other) tissue and ethylene production was determined for each as described above. Tissues were weighed and oxidized and radioactivity in each sample was quantitated using liquid scintillation spectrometry as described by Sterling and Lownds (1992). Recovery of radiolabel applied was $>93 \%$.

Daily maximum and minimum temperature data were obtained from the USGS (Desert Winds Project, Flagstaff, Ariz.) meteorological station located $0.9 \mathrm{~km}$ northeast of the study site (Table 1). Precipitation was recorded daily at the study site.

Values for picloram uptake and picloram-induced ethylene production for each collection date were averaged and standard errors were calculated. In addition, multiple regressions were developed for picloram uptake expressed as percent of picloram applied or picloram concentration (nmol picloram $\mathrm{g}^{-1}$ fresh weight) in leaf, other and total tissue, and using as predictor variables average precipitation $(\mathrm{cm})$ and/or one of average maximum, minimum, and average daily temperature $\left({ }^{\circ} \mathrm{C}\right)$ averaged over 1,2 , 7 , or 14 days prior to application. Similarly, picloram-induced ethylene production $\left[\log 10\left(\mathrm{nl} \mathrm{h}^{-1} \mathrm{~g}^{-1}\right.\right.$ fresh weight +1$\left.)\right]$ by treated leaf, other tissue or total tissue as a percent of respective control (untreated leaf, other or total tissue), was modeled using as predictor variables picloram uptake (percent of picloram applied) or picloram concentration (nmol g ${ }^{-1}$ fresh weight) and/or average precipitation $(\mathrm{cm})$ and/or one of minimum, maximum, and average daily temperature $\left({ }^{\circ} \mathrm{C}\right.$ ) and precipitation $(\mathrm{cm})$ averaged over $1,2,7$, or 14 days prior to application. The set of plants from which tissue was collected did not influence picloram uptake or picloram-induced ethylene production; therefore, data for each plant set were pooled for analysis. Finally, an analysis of variance was conducted to compare months for picloram uptake and induced ethylene production. When the analysis of variance $F$ test was significant, month means were separated using Least Significant Difference.

\section{Results}

\section{Ethylene Time Course}

Picloram-induced ethylene production by whole plants increased 20- to 45-fold over time compared to the control, saturating between 72 and 120 hours after treatment for each picloram concentration applied $(\mathrm{P}<0.05$ ) (Fig. 1). At 24 hours, the 2 highest rates of picloram-induced ethylene production were ca. 20 -fold over the control. Plants treated with the 2 higher rates died within 4 weeks and those treated with the lower rate died after 16 weeks (data not shown). Picloram-induced ethylene production 24 hours after treatment was linearly related to visual ratings of plant chlorosis from 24 hours to 16 days after treatment, averaged across picloram rates [chlorosis $=-6.0+0.95$ (ethylene production); $r=0.84 ; \mathrm{P}=0.001]$. Therefore, for the following experiment, ethylene production was measured after 24 hours as an indicator of broom snakeweed's physiological sensitivity to the herbicide. 
Table 1. Stuly period ${ }^{1}$ and long-term ${ }^{2}$ averages for monthly precipitation and average daily maximum and minimum temperatures per month near the Coop Well on the USDA Jornada Experimental Range.

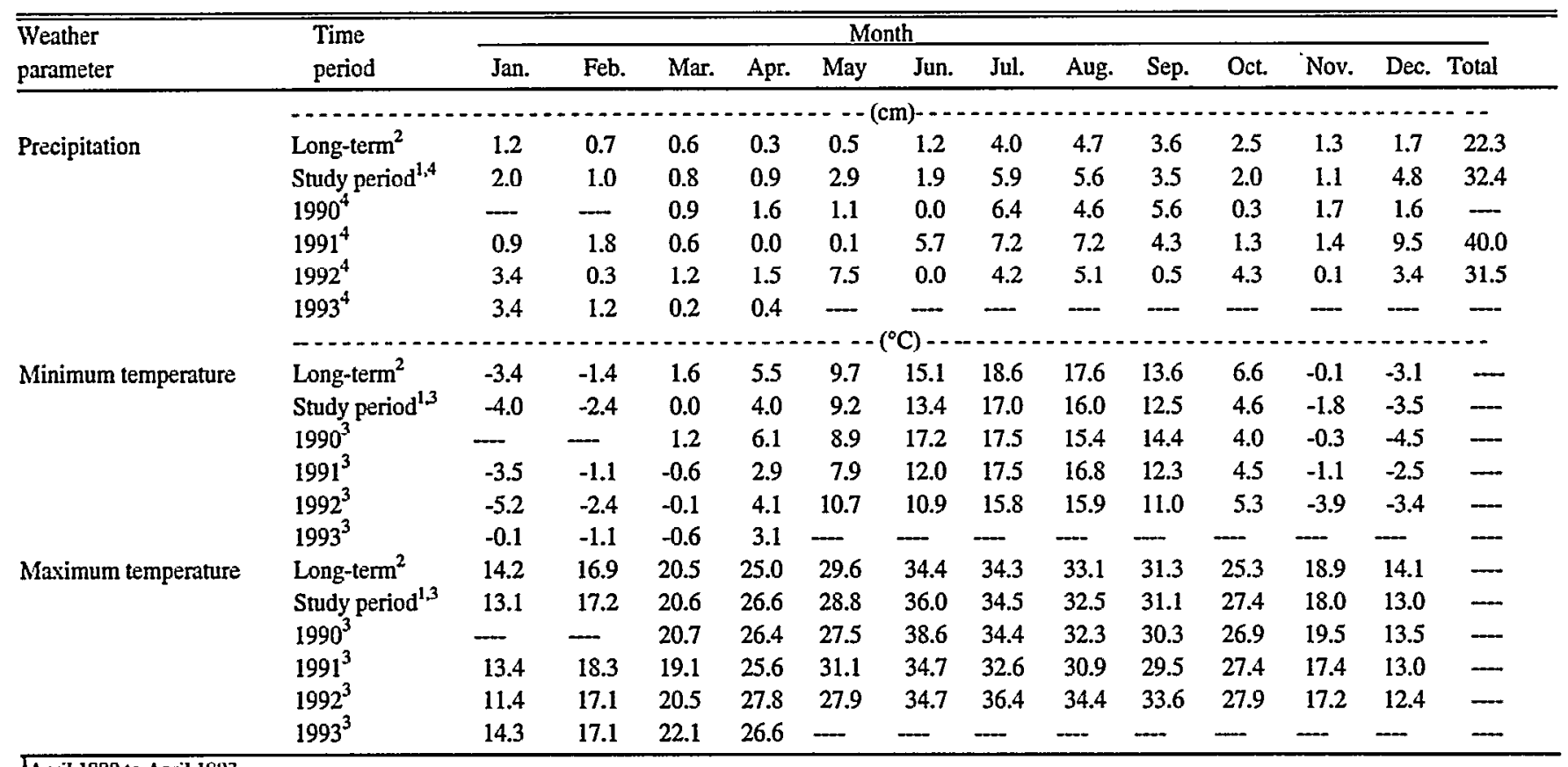

April 1990 to April 1993.

2Thirty year (1959 to 1989); Source: National Oceanic and Atmospheric Administration.

3Source: USGS Meteorological Station equipped by the Desert Winds Project in Flagstaff, Ariz.

${ }^{4}$ Source: Dr. Robert Gibbens, USDA-ARS, Las Cruces, N.M.

\section{Picloram Uptake and Induced Ethylene Production in the} Field

Picloram uptake by field-collected broom snakeweed tissue varied with collection date (Fig. 2). Average picloram uptake by total tissue on each date ranged from 1.5 to $46.2 \%$ of applied with an overall mean of $11.4 \%$ of applied and from 0.17 to $4.65 \mathrm{nmol}$ $\mathrm{g}^{-1}$ fresh wt with an overall mean of $1.09 \mathrm{nmol} \mathrm{g}^{-1}$ fresh wt. Approximately $73 \%$ of absorbed picloram remained in treated leaves with $27 \%$ of absorbed in other, untreated tissues (data not shown).

Average picloram-induced ethylene production was greater in leaf tissue compared to other tissue. Average picloram-induced ethylene production by leaf tissue for each collection date ranged from 80 to $1.5 \times 10^{5} \%$ of control with an overall mean of $8,700 \%$ of control and for other tissue ranged from 40 to $680 \%$ of control

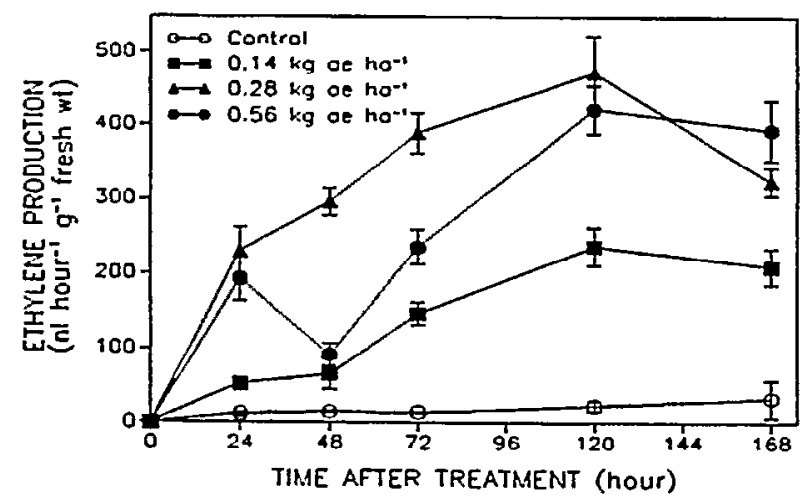

Fig. 1. Picloram-induced ethylenc production over time by greenhouse-grown broom snakeweed plants sprayed with increasing picloram rates. Each value is the average of 6 replications \pm SE. with an overall mean of $145 \%$ of control (data not shown). Average ethylene production by total tissue for each collection date ranged from 50 to $791 \%$ of control with an overall mean of $175 \%$ of control (Fig. 3). These values are similar to ethylene production induced in picloram-treated greenhouse plants after 24 hours (Fig. 1). Control values for picloram-induced ethylene production were not different over collection dates (data not shown).

Picloram uptake and picloram-induced ethylene production varied with month, an approximation for stage of plant growth (Table 2). Average picloram concentration per month was over 7fold greater in July and August compared to March when uptake was least $(\mathrm{P}<0.05$; Table 2). In addition, picloram uptake as percent of applied picloram was greatest in July and August as well as January compared to most other months. Average picloraminduced ethylene production by total tissue per month was greatest in August at more than $400 \%$ control $(\mathrm{P}<0.05)$ (Table 2).

To determine relationships between environmental conditions previous to treatment and picloram uptake or induced ethylene production, precipitation and temperature $1,2,7$ or 14 days prior to application, picloram uptake and picloram-induced ethylene production were modeled. The best regression equations for uptake and picloram-induced ethylene production were generated from precipitation and temperature averaged over the 7 days prior to treatment compared to precipitation and temperature averaged over 1,2 , or 14 days prior to treatment (data not shown). Positive relationships were found between the predictors average precipitation and minimum temperature 7 days prior to treatment and the picloram responses, picloram uptake expressed as percent of applied $\left(\mathrm{P}=0.0001 ; \mathrm{R}^{2}=0.201\right)$ and concentration $\left(\mathrm{nmol} \mathrm{g}{ }^{-1}\right.$ fresh wt) $\left(P=0.0001 ; R^{2}=0.247\right)$ (Table 3). Alternatively, average minimum temperature alone was positively related with picloram concentration $\left(\mathrm{P}=0.0001 ; \mathrm{R}^{2}=0.235\right.$ ) (Table 3 ). Consistent with these 
Table 2. Picloram uptake by broom snakeweed tissue after 24-hour incubation averaged over month for a 36-month period.

\begin{tabular}{|c|c|c|c|c|}
\hline Month & $\begin{array}{l}\text { Approximate } \\
\text { stage of } \\
\text { growth }\end{array}$ & \multicolumn{2}{|c|}{ Picloram uptake } & $\begin{array}{l}\text { Picloram-induced } \\
\text { ethylene production } \\
\text { by total tissue } \\
\text { (\% of control) } \\
\left(\mathrm{nl} \mathrm{h}^{-1} \mathrm{~g}^{-1} \text { fresh } \mathrm{wt}\right)\end{array}$ \\
\hline Jan. & Winter dormancy & $0.86(0.19) b c^{2}$ & $16.1(1.7) b c$ & $157 \mathrm{bc}$ \\
\hline Feb. & Winter dormancy & $0.63(0.19) \mathrm{ab}$ & $11.9(1.6) \mathrm{ab}$ & $155 \mathrm{bc}$ \\
\hline Mar. & Shoot regreening & $0.29(0.17) \mathrm{a}$ & $8.2(0.2) \mathrm{a}$ & $146 \mathrm{bc}$ \\
\hline Jun. & Leaves die back & $1.12(0.16) \mathrm{cd}$ & $9.8(1.3) \mathrm{a}$ & 158 be \\
\hline Jul. & Shoot regreening & $2.10(0.16) \mathrm{e}$ & $15.1(1.4) b c$ & $212 b$ \\
\hline Aug. & Floral buds emerge & $2.03(0.16) \mathrm{e}$ & $18.3(1.4) \mathrm{c}$ & $423 a$ \\
\hline Sep. & Flowering & $1.41(0.15) \mathrm{d}$ & $11.5(1.3) \mathrm{a}$ & $172 b c$ \\
\hline Oct. & Fruit developing & $1.41(0.13) \mathrm{d}$ & $10.2(1.1) \mathrm{a}$ & $132 \mathrm{c}$ \\
\hline Nov. & Shoot die back & $0.84(0.17)$ bc & $10.2(1.5) \mathrm{a}$ & $131 \mathrm{c}$ \\
\hline
\end{tabular}

Phenological ctuges of growth (Depuit and Caldwell 1975).

${ }^{2}$ Each value is the average (numbers in parentheses are the standard errors); means within a column followed by same letter do not differ ( $\left.P>0.05\right)$.

positive relationships, picloram tissue concentration was greatest when treated during July and August (Table 2), months with the highest precipitation and high temperatures (Table 1).

Picloram-induced ethylene production by leaf tissue was not predicted well by any of the predictors evaluated ( $P>0.074$ for all models) (Table 3), possibly due to high levels of picloram in the leaf tissue resulting in saturation of picloram-induced ethylene production. Picloram-induced ethylene production by other tissue was best predicted by precipitation, average maximum temperature 7 days prior to treatment and percent of applied picloram translocated to other tissue $\left(P=0.0001 ; R^{2}=0.162\right)$ (Table 3 ). picloram-induced ethylene production by total tissue was best predicted by the minimum temperature and precipitation 7 days prior to treatment and picloram concentration in total tissue $\left(P=0.0001 ; R^{2}=0.226\right)$; however, average precipitation 7 days prior to treatment and picloram concentration predicted ethylene induction similarly ( $\left.P=0.0001 ; R^{2}=0.224\right)$ (Table 3$)$. Therefore, the amount of picloram absorbed and the environment prior to application both contribute to the ethylene production response of broom snakeweed to picloram. While picloram-induced ethylene production was best modeled using temperature, precipitation and uptake, it is important to note that over 36 months and a range of conditions, picloram-induced ethylene production was related to picloram uptake (Table 3 ).

\section{Discussion and Conclusions}

The amount of picloram absorbed and the environmental conditions, precipitation and temperature, prior to application contributed to the physiological sensitivity of broom snakeweed to picloram as measured by picloram-induced ethylene production. In general, picloram uptake and the induced response, ethylene production, were greatest after high temperature and precipitation 7 days prior to herbicide application, corresponding to the phenological stages, shoot regreening and flower bud emergence during July and August in southern New Mexico. Specifically, picloram uptake (percent of applied and tissue concentration) was positively related to average minimum temperature and precipitation 7 days prior to treatment, and picloram-induced ethylene production by total tissue was positively correlated with picloram tissue concentration and average precipitation and/or minimum temper-

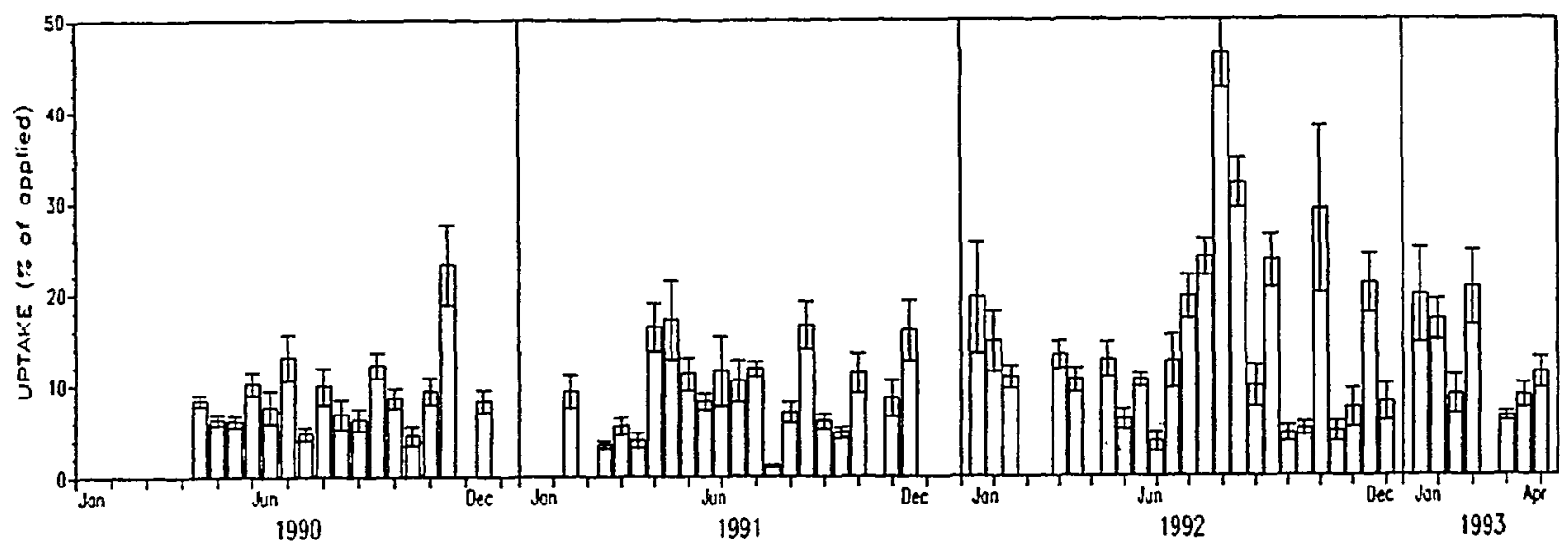

Fig. 2. Picloram uptake (percent of applied) by field-grown broom snakeweed tissue after 24-hour incubation for each collection date over a 36-month period. Each value is the average ( $\pm S E$ are represented by bars). 
ature 7 days prior to treatment (Table 3). Both picloram uptake and picloram-induced ethylene production were greatest during the months of July and August, months with high precipitation and temperatures (Table 2).

If we interpret the relation between induced ethylene and picloram concentration as ethylene production being a picloraminduced response in broom snakeweed as it is in other species (Hall et al. 1985) and for other auxins (Lownds et al. 1987, Yang et al. 1990), it may be important in picloram efficacy. The relationship between picloram uptake and ethylene production suggests that measuring ethylene production 24 hours after treatment may provide an indirect measure of picloram uptake. In addition, since herbicide-induced ethylene production is in some species an important component of the overall herbicide response (Hall et al. 1985), a differential ethylene response by broom snakeweed might also affect picloram efficacy. Picloram induced marked epinasty and chlorosis of broom snakeweed plants, responses which would likely result in reduced photosynthesis, as measured in other species (Woodrow and Grodzinski 1989). Finally, prolonged high ethylene production (Fig. 1) would require reallocation of plant resources to ethylene synthesis which could lead to further plant decline.

Picloram uptake by broom snakeweed leaves averaged ca. $11 \%$ of applied over 36 months, a value similar to $15 \%$ of picloram applied to broom snakeweed plants grown in greenhouse conditions (Sterling and Lownds 1992). Average picloram uptake per application ranged from 2 to $46 \%$ of applied (Fig. 2) with uptake increasing when temperature and precipitation prior to application were high (Table 2). Similarly, flux of the tracer, Rb phos- phate, across isolated cuticles was least for cuticles that had developed at lower temperature and/or lower light intensity combinations (Reed and Tukey 1982). In contrast, 1-napthylacetic acid (NAA) penetration rates decreased across cuticles isolated from Pisum sativum leaves developed under decreased soil moisture content and relative humidity, conditions which increased cuticle thickness (Hunt and Baker 1982). Picloram uptake by leaves of Canada thistle (Cirsium arvense L.) (Lauridson et al. 1983) or Russian knapweed (Centaurea repens L.) (Morrison et al. 1995) was unaffected by soil moisture previous to application and clopyralid acid uptake was not different for plants grown under low relative humidity or water stress conditions (Kloppenburg and Hall 1990). Therefore, herbicide uptake response by plants grown in different environmental conditions appears species, and likely compound, specific.

In field studies in New Mexico and Texas, broom snakeweed was most responsive to picloram application in its post-bloom stage in warm temperature and moist soil conditions (Sosobee 1985) and from October to December (McDaniel and Duncan 1987) or in April and May in high moisture and soil temperature conditions (Gesink et al. 1973, Schmutz and Little 1970). These field results agree with our model in terms of increased uptake and ethylene production after periods of high moisture. In contrast, October to December were periods of time when uptake and ethylene production were generally low in our study. This response would be predicted by our model based on low rainfall in 1990 and 1991 (Table 1). In contrast, rainfall was high in October and December in 1992 (Table 1) and correspondingly with high uptake and ethylene production (Fig. 2 and 3). In con-

Table 3.Best regression equations for picloram uptake and picloram-induced ethylene production by broom snakeweed leaf tissue. Weather data are averaged 7 days before treatment.

\begin{tabular}{|c|c|c|c|c|c|}
\hline Dependent variable & Estimated equation & & $\mathbf{n}$ & $\mathrm{P}^{1}$ & $\overline{\mathrm{R}^{2}}$ \\
\hline $\begin{array}{l}\hat{(\hat{Y})} \\
\text { Picloram uptake (\% of applied) }\end{array}$ & 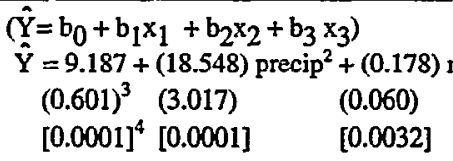 & mintemp & 527 & 0.0001 & 0.201 \\
\hline $\begin{array}{l}\text { Picloram concentration } \\
\left(\mathrm{nmol} \mathrm{g}^{-1} \text { fresh } \mathrm{wt}\right)\end{array}$ & $\begin{array}{cc}\hat{\mathrm{Y}}= & 0.669+(1.003) \text { precip }+(0.064) \mathrm{mir} \\
(0.072)(0.361) & (0.007) \\
{[0.0001][0.0057]} & {[0.0001]}\end{array}$ & atemp & 512 & 0.0001 & 0.247 \\
\hline $\begin{array}{l}\text { Ethylene induced in treated leaf } \\
{\left[\log 10\left(\mathrm{nl} \mathrm{h}^{-1} \mathrm{~g}^{-1} \text { fresh wt }+1\right)\right]}\end{array}$ & \multicolumn{2}{|l|}{ None significant } & 370 & $>0.0740$ & $<0.099$ \\
\hline $\begin{array}{l}\text { Ethylene induced in total tissue } \\
{\left[\log 10\left(\mathrm{nl} \mathrm{h}^{-1} \mathrm{~g}^{-1} \text { fresh wt }+1\right)\right]}\end{array}$ & 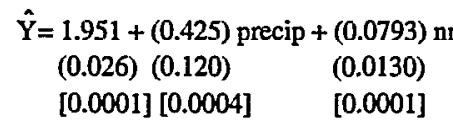 & mol $g^{-1}$ fresh wt & 370 & 0.0001 & 0.224 \\
\hline
\end{tabular}

${ }^{\mathrm{P}}$ is overall significance level for estimated equation.

${ }^{2}$ Abbreviations: precip is average daily precipitation for prior 7 days; mintemp is average daily minimum temperature for prior 7 days; maxtemp is average daily maximum temperature for prior 7 days; meantemp is average daily temperature (maximum + minimum +2 ) for prior 7 days.

${ }^{3}$ Numbers in parentheses below slope coefficients are standard error of estimate.

${ }^{4}$ Numbers in brackets are level of significance for estimate. 


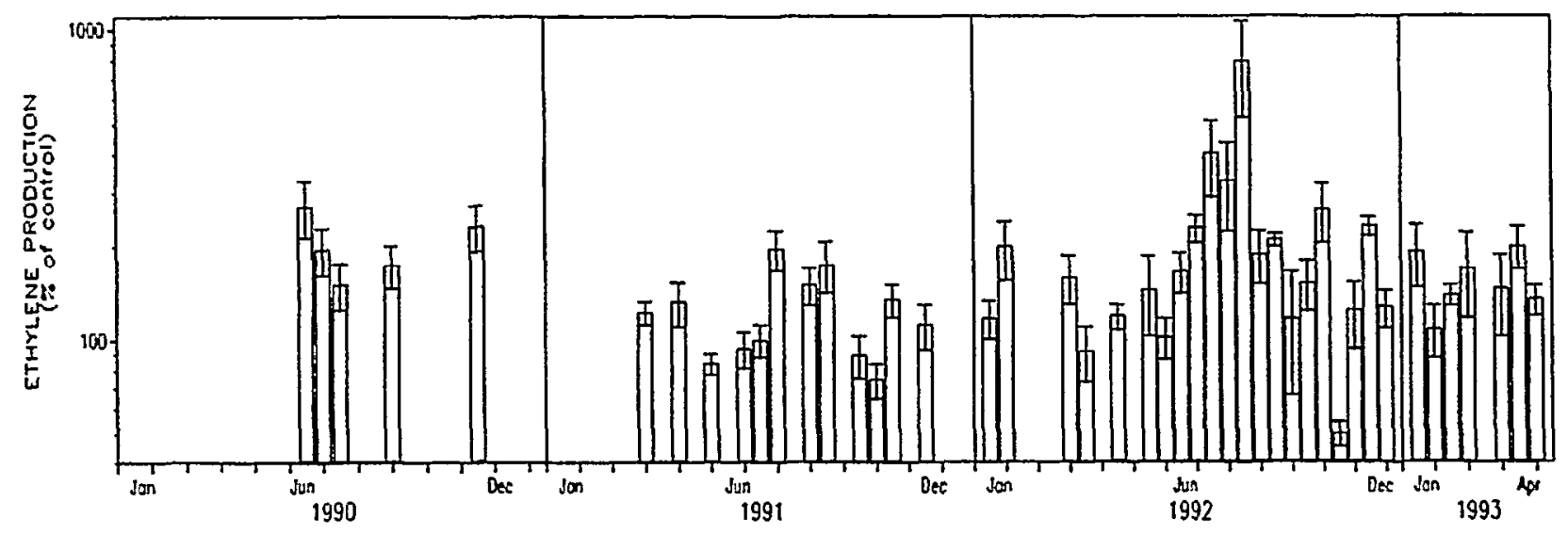

Fig. 3. Picloram-induced ethylene production (nmol $\mathrm{g}^{1}$ fresh weight) as a percent of control by field-grown broom snakeweed tissue after 24 hour incubation for each collection date over a 36-month period. Each value is the average ( \pm SE are represented by bars).

trast, rainfall was generally high in April and May (Table 1), but uptake was average (Fig. 2) suggesting that increased picloram uptake and picloram-induced ethylene production probably are not the only factors controlling differential tolerance to picloram. This contrast may suggest that only small amounts of picloram uptake are necessary for efficacy such that even in conditions with low uptake, enough picloram is in the plant for herbicidal effects. In addition, picloram-induced response (ethylene production and/or length of time ethylene is produced) may vary with environmental conditions resulting in variable herbicide response. Specifics of this response and any role in herbicide efficacy will require further study. Alternatively, sensitivity differences across stages of plant growth may be related more strongly to differences in picloram translocation during periods of nonstructural carbohydrate storage (Lym and Messersmith 1991, Sosobee $1985)$ or to differences in picloram metabolism to nontoxic metabolites. Future studies will evaluate the role of picloram translocation and metabolism in picloram efficacy as related to stage of plant growth and environmental conditions previous to application.

The best fit models explained a maximum of $25 \%$ of the variability in picloram uptake or picloram-induced ethylene production but should be useful in predicting the best times to apply herbicide to maximize uptake. Alternative predictive methods are based on calendar date for which there may be large differences in rainfall and temperature from one year to the next (Table 1) resulting in highly variable responses. In addition, other variables not used in these models might have influenced picloram uptake or picloram-induced ethylene production such as relative humidity previous to application (Kloppenburg and Hall 1990) or plant water status at the time of application (Morrison et al. 1995).

\section{Literature Cited}

Depuit, E.J. and M.M. Caldwell. 1975. Gas exchange of three cool semidesert species in relation to temperature and water stress. J. Ecol. 63:835-858.

Fedtke, C. 1982. Biochemistry and physiology of herbicide action, first edition. Springer-Verlag, New York, N.Y.
Gesink, R.W., H.P. Alley, and G.A. Lee. 1973. Vegetative response to chemical control of broom snakeweed on a blue grama range. J. Range Manage. 26:139-143.

Hall, J.C., P.K. Bassi, M.S. Spencer, and W.H. Vanden Born. 1985. An evaluation of the role of ethylene in herbicidal injury induced by picloram or clopyralid in rapeseed and sunflower plants. Plant Physiol. 79:18-23.

Hunt, G.M. and E.A. Baker. 1982. Developmental and environmental variations in plant epicuticular waxes: Some effects on the penetration of naphthylacetic acid, p. 279-292. In: D.F. Cutler, K.L. Alvin, and C.E. Price (eds), The plant cuticle. Academic Press, London.

Kloppenburg, D.J. and J.C. Hall. 1990. Effects of formulation and environment on absorption and translocation of clopyralid in Cirsium arvense (L.) Scop. and Polygonum convolvulus L. Weed Res. 30:9-20.

Lane, M.A. 1985. Taxonomy of Gutierrezia (Compositae: Astereae) in North America. Syst. Bot. 10:7-28.

Lauridson, T.C., R.G. Wilson, and L.C. Haderlie. 1983. Effect of moisture stress on Canada thistle (Cirsium arvense) control. Weed Sci. 31:674-680.

Lownds, N.K., J.M. Leon, and M.J. Bukovac. 1987. Effect of surfactants on foliar penetration of NAA and NAA-induced ethylene evolution in cowpea. J. Amer. Soc. Hort. Sci. 112:554-560.

Lym, R.G. and C.G. Messersmith. 1991. Correlation of environment and root carbohydrate content to picloram translocation in leafy spurge. $\mathrm{J}$. Range Manage. 44:254-258.

McDaniel, K.C. and K.W. Duncan. 1987. Broom snakeweed (Gutierrezia sarothrae) control with picloram and metsulfuron. Weed Sci. 35:837-841.

McDaniel, K.C., R.D. Pieper, and G.B. Donart. 1982. Grass response following thinning of broom snakeweed. J. Range Manage. 35:219-222.

Morrison, R.G., N.K. Lownds, and T.M. Sterling. 1995. Picloram uptake, translocation, and efficacy in relation to water status of Russian knapweed (Centaurea repens L.). Weed Sci. 43:34-39.

National Oceanographic and Atmospheric Administration. 1989. Climatological data, New Mexico, Vol. 93.

Reed, D.W. and H.B. Tukey, Jr. 1982. Permeability of Brussels sprouts and carnation cuticles from leaves developed in different temperatures and light intensities, p. 267-278. In: D.F. Cutler, K.L. Alvin, and C.E. Price (eds), The plant cuticle. Academic Press, London.

Schmutz, E. M. and D. E. Little. 1970. Effects of 2,4,5-T and picloram on broom snakeweed in Arizona. J. Range Manage. 23:354-357.

Sosobee, R.E. 1985. Timing-The key to herbicidal control of broom snakeweed. Texas Tech Management Note 6. Texas Tech Univ., Lubbock, Tex.

Sterling, T.M. and N.K. Lownds. 1992. Picloram absorption by broom snakeweed (Gutierrezia sarothrae) leaf tissue. Weed Sci. 40:390-394.

Woodrow, L. and B. Grodzinski. 1989. An evaluation of the effects of ethylene on carbon assimilation in Lycopersicon esculentum Mill. J. Exp. Bot. 40:361-368.

Yang, S.F., W.K. Yip, and J.G. Dong. 1990. Mechanism and regulation of ethylene biosynthesis, p. 24-35. In: H.E. Flores, R.N. Arteca, and J.C. Shannon (eds), Polyamines and ethylene: Biochemistry, physiology, and interactions. Current topics in plant physiology: An American Society of Plant Physiologists Series, Vol. 5. American Society of Plant Physiologists, Rockville, Md. 